\title{
Supporting agricultural resilience: The value of women farmers' communication practices
}

SPECIAL ISSUE: MORE THAN VALUE\$ IN THE FOOD SYSTEM

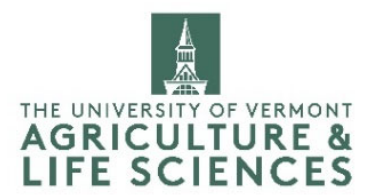

Submitted September 10, 2019 / Revised December 23, 2019, and March 30, 2020 /

Accepted April 6, 2020 / Published online July 22, 2020

Citation: Daigle, K., \& Heiss, S. N. (2020). Supporting agricultural resilience: The value of women farmers' communication practices. Journal of Agriculture, Food Systems, and Community

Development, 9(4), 45-63. https://doi.org/10.5304/jafscd.2020.094.010

Copyright $(C) 2020$ by the Authors. Published by the Lyson Center for Civic Agriculture and Food Systems. Open access under CC-BY license.

\begin{abstract}
While women in the United States (U.S.) are increasingly entering into or being recognized for their role as farm operators, researchers argue that women farmers have been and continue to be under-recognized and researched. In the face of increasing environmental and financial challenges, as well as a variety of challenges related to domestic life, women farmers remain resilient. Buzzanell's (2010) resilience communication theory suggests that forming and maintaining communication networks is essential to resilience processes. Drawing on interviews with 35 U.S. women farmers, we argue that communication networking is valuable to food systems; specifically, these practices contributed to and reified the resilience of the individual farmers, their farm business, and the greater sus-

a* Corresponding author: Kerry Daigle, University of Vermont, 002 Morrill Hall, 146 University Place; Burlington, VT 05405 USA; +1-802-656-2001; kjdaigle@uvm.edu

b Sarah N. Heiss, Department of Community Development and Applied Economics, University of Vermont; 208F Morrill Hall, 146 University Place; Burlington, VT 05405 USA.
\end{abstract}

tainable agriculture sector. Implications for women farmers as a community of practice, as well as organizations serving these populations, are discussed.

\section{Keywords}

Women Farmers, Resilience Communication, Sustainable Agriculture, Community of Practice

\section{Introduction}

According to the 2017 U.S. Department of Agriculture (USDA) census of agriculture, $56 \%$ of farms have at least one woman operator and a third of farms have a woman principal operator (USDA, 2019). Due to both a rise in women entering farming, as well as more accurate identification of existing women farmers, this statistic reflects a $27 \%$ increase in women farmers since the previous census in 2012 (USDA, 2014, 2019). Despite these rising numbers, the exclusion of women in land

\section{Funding Disclosure}

This project was funded by support from a 2018 Hatch grant through the Vermont Agricultural Experimentation Station. 
property rights and subsequent characterization of women as farm wives have left women overlooked in traditional, conventional farm models (Keller, 2014; Leckie, 1996; Trauger, 2004). On average, women farmers today operate smaller farms for lower wages (Allen \& Sachs, 2011), and are three times more likely to operate farms participating in sustainable agriculture (Trauger et al., 2008). Sustainable agriculture refers to farming methods that "equitably balance concerns of environmental soundness, economic viability, and social justice among all sectors in society" (Allen, Van Dusen, Lundy, Gliessman, 1991, p. 37). Prior scholars have argued that farmers in sustainable agriculture operate within a separate paradigm, one that is concerned more about connecting to and protecting the earth than about money (Bell, 2004; Beus \& Dunlap, 1990). Research has contributed to an increased understanding of women farmers' position and experiences in sustainable agriculture in the United States (Barbercheck, Brasier, Kiernan, Sachs, \& Trauger, 2014; Hassanein, 1997; Sachs, Barbercheck, Brasier, Kiernan, \& Terman, 2016; Trauger, 2004). Yet, more information is needed to observe ways women farmers in sustainable agriculture access resources for support through the challenges of farming (Sachs et al., 2016). This research seeks to fill that need by highlighting the networks women draw on for support amid financial and environmental challenges, as well as challenges related to gender and farming.

Resilience communication theory (Buzzanell, 2010) is a useful lens for examining how women farmers develop or maintain resilience to the challenges of farming. A communication lens frames resilience as a dynamic, on-going process that is cocreated among people through discourse, interaction, and material considerations. Adopting a communicative lens for resilience is valuable because it examines the processes by which resilience is developed and maintained in community with others.

A key component of the resilience process is a person or community's ability to maintain and use communication networks (Buzzanell, 2010). Current research demonstrates that in response to difficulties related to professional development, women farmers have developed networking practices that differ from the practices of men. Women farmers have been found to rely on both formal and informal support networks to facilitate their success in agriculture (Barbercheck et al., 2014; Hassanein, 1997; Trauger, Sachs, Barbercheck, Brasier, Kiernan, 2010).

While we know that women draw on communication networks for support (Hassanein, 1997, 1999), more research is needed to understand how these networks are maintained through communication, as well as the impact of these communication practices. The current study explores how women farmers maintain and use communication networks in agriculture. In addition to exploring their networking practices, we examine the value of these communication practices to women farmers' resilience in complex and often overlapping, economic, environmental, and social systems. We aim to develop a set of recommendations related to how individual women farmers, as well as the formal organizations that serve them, can best support the persistence and resilience of women farmers. Our suggested practices will both support women farmers and highlight how adequately supporting their communication practices can contribute to community and environmental resilience more generally.

\section{Gender and Farming}

While there is nothing "inherently feminine or masculine" about agricultural tasks, cultural and social formations deeply affect theoretical and realized positions of different genders in farming (Leckie, 1996, p. 310). In the United States, a long history of gender discrimination has shaped the position of women in agricultural contexts today. Traditionally, inheritance laws that pass land ownership from father to son maintained a system where most women entered farming through marriage to a farmer. In this arrangement, men had access to ownership and operation of the farm, while the woman assumed the role of farm wife. The Homestead Act of 1862 lifted prohibitive legal barriers to enable single women head of households to own land; however, the internalization of women as farm wives persists (Horst \& Marion, 2019).

Past research has demonstrated how the misunderstanding of women farmers' contributions has led to their exclusion in agricultural infor- 
mation and knowledge exchange (Leckie, 1996; Trauger et al., 2008). For example, a young woman farmer in Ontario was "never trusted to drive" because her town lacked recognition of women as legitimate farmers, which negatively affected the tasks her father perceived her to be capable of learning (Leckie, 1996, p. 320). In this case, socially constructed ideas of women farmers turned into concrete outcomes, as women grow up to lack the full set of skills they need to participate in all agricultural tasks.

On a larger scale, Trauger and colleagues (2008) argued that "long-held social constructions of women as farm wives or 'bookkeepers' rather than farmers or decision-makers influence the direction of most educational programming delivered through extension programs in land-grant universities in the United States" (p. 432). Instead of helping women overcome constraints to participation, these institutions continue to reproduce prohibitive barriers; thus, this trend is perpetuated by institutions failing to support women's educational needs such as machinery training, a hands-on and interactive learning style, and space to ask questions openly and without concern for being perceived negatively by men farmers (Barbercheck et al., 2009; Brasier, Barbercheck, Kiernan, Sachs, Schwartzberg, \& Trauger, 2009).

\section{Women in Sustainable Agriculture}

According to the U.S. census of agriculture, women are three times as likely to operate farms practicing sustainable farming methods than traditional, conventional agriculture (Trauger, 2004). Sustainable agriculture is not immune to modern financial and environmental challenges; however, participants seek to counter the problematic notions of industrial agriculture through an emphasis on norms such as decentralization, community, harmony with nature, and crop diversity (Beus \& Dunlap, 1990). In these contexts, farmers highly value social relations and greater dialogue among farmers to improve one's farming knowledge and the collective experience of the farming community (Bell, 2004). While men still maintain some gendered identities on the farm, overall, success in sustainable agriculture requires an "altered social arena" that encourages openness and acceptance of all voices (Peter, Bell, Jarnagin, \& Bauer, 2000, p. 216).

The literature on women farmers' role in sustainable agriculture is well-established (Chiappe \& Butler Flora, 1998; Sachs et al., 2016; Trauger, 2004; Trauger et al., 2008). Women's farming practices within sustainable agriculture emphasize environmental and social well-being, as well as food quality, over agricultural intensification (Barbercheck, Brasier, Biernen, Sachs, \& Trauger, 2014; Trauger et al., 2010). Other recent scholars suggest that women perform and reinforce femininity by bringing qualities of care to their farming practices, which highlights how women's practices take care of the earth, their customers, and other farmers (Jarosz, 2011; Shisler \& Sbicca, 2019).

In recent work, The Rise of Women Farmers and Sustainable Agriculture, Sachs et al. (2016) introduce the feminist agri-food systems theory (FAST) as a tool to conceptualize women farmers' role in sustainable farming systems in the Northeast. According to FAST, women in agriculture do not necessarily identify as feminists, but they do assert themselves as farmers, which, in itself, challenges traditional patriarchal conceptions of farm compositions. Similarly, Trauger (2004) argued that women's identities were central to their social identities within agriculture. Although "work roles of women in sustainable agriculture are similar to the work of women in conventional agriculture," women identified as farmers within sustainable agriculture and as farmwives within conventional agriculture (p. 303).

While women's work is more recognized and welcomed in sustainable agriculture, agricultural research, policies, and organizations often overlook other forms of marginalization within sustainable agriculture. As women contend with barriers to land, capital, credit, and information, they have increasingly found their place in alternative agri-food movements that resist the rigid gender norms of conventional agriculture (Sachs et al., 2016; Trauger, 2004). However, the lessening of gender inequality within sustainable agriculture spaces does not dissolve steep economic and social barriers to participation (Pilgeram, 2019). Women are often able to overcome these challenges, but it is overwhelmingly those with the privileged racial, 
ethnic, and socioeconomic status to do so (Pilgeram, 2019; Sachs et al., 2016). Therefore, alternative agricultural movements offer narrow opportunities for mobility and exclude farmers whose identity intersects multiple forms of marginalization such as gender and race, sexuality, or socioeconomic status (Leslie, \& White, 2018; Leslie, Wypler, \& Bell, 2019; Wypler, 2018).

FAST also describes women's roles in agricultural organizations and associated networking structures. Because traditional means of organizing within agriculture, such as extension outreach efforts, do not typically recognize women as farmers, women seek out alternative communities of practice. Communities of practice, unlike communities bound by geographic location or familial relationships, refer to groups of people who genuinely care about the same real-life problems or topics, and who regularly interact to learn together and from each other (Wenger, McDermott, \& Snyder, 2002). Sachs and colleagues' (2016) FAST found that U.S. women farmers use communities of practice associated with farming networks such as the Women's Agricultural Network (WagN) or the Women, Food and Agriculture Network (WFAN). Both of these organizations seek to train, engage, and connect women involved in farm work across the United States. This component of the FAST complements past research on unique behaviors in women farmers' networking preferences (Hassanein, 1997; Trauger et al., 2010). However, according to Sachs and colleagues (2016), future research drawing on FAST should build on past research by looking at how women's networking practices evolve alongside their shifting roles in agriculture. This gap in the women farmer research parallels a need within communication literature. While communities of practice is a well-established area of study, more research is needed to understand the development and maintenance of these on-going, organizing practices that allow groups to purposefully and spontaneously "think together" and talk about, cope with, and thrive within complex issues and challenging experiences (Pyrko, Dörfler, \& Eden, 2017, p. 390).

\section{Resilience Communication}

While sustainable farming operations provide a space for women to experience less gender exclusion, feel aligned with values of nourishing others, and to better assert their identities as farmers, life on sustainable farms should not be romanticized. All farm work requires endless hours, is physically demanding, and often takes place in socially and geographically isolated areas (Brew, Inder, Allen, Thomas, \& Kelly, 2016). Further, in the $21^{\text {st }}$ century, the spread of large scale, industrial agriculture has exacerbated economic and environmental challenges for small farmers (Altieri, 2009). Lastly, women still experience challenges related to their position in a male-dominated work environment (Peter et al., 2000; Shisler \& Sbicca, 2019). More research is needed to understand how women farmers access support networks to overcome these economic, environmental, and social challenges on their farms.

Buzzanell's (2010) theory of resilience communication is a useful framework for understanding how women farmers build and maintain agricultural networks. It is also useful in understanding how their networking practices help them to adapt and bounce forward after disruptions or amidst continued stressors (Buzzanell, 2010; Houston, 2015, 2018; Norris, Stevens, Pfefferbaum, Wyche, \& Pfefferbaum, 2008 ). Resilience can be understood as an individual or groups' ability to bounce back or reintegrate after a disturbance (Buzzanell, 2010; Manyena, O’Brien, O’Keefe, \& Rose, 2011). Early literature considered a "disturbance" to require a catastrophic event such as traumatic incidents of natural disaster and loss. However, scholars now include "reoccurring and sometimes anticipated losses that disrupt and challenge everyday life" (Long et al., 2015, p. 67). Conceptions of resilience have since been extended to not only consider how those involved return to baseline, but how they adapt or bounce forward through these challenges (Houston, 2015; Manyena et al., 2011; Richardson, 2002). The idea of "bouncing forward" views disaster as an opportunity for local livelihood enhancement rather than as a simple return to status quo ante (Manyena et al., 2011, p. 7).

Resilience as a communication process recognizes that resilience is not something that is achieved. Rather, it is a dynamic process that unfolds over time through the way people collabora- 
tively make shared meaning of their experiences through discourse, interaction, and material consideration (Buzzanell, 2010). Buzzanell (2010) developed the foundational theory of resilience communication, which understands resilience as the culmination of five interactive processes (Figure 1): (a) crafting normalcy; (b) affirming identity anchors; (c) maintaining and using communication networks; (d) putting alternative logics to work; and (e) legitimizing negative feelings while foregrounding productive action.

In response to agricultural literature on women farmers' networking practices, this study focuses on the third process of developing and using communication networks. Communication networks refer to individuals and organizations that are connected through relationships and symbolic activity within a specific social context (Monge, Heiss, \& Margolin, 2008). Communication networks can be used to obtain information, report, regulate, cooperate, or compete, in addition to a host of other possibilities. They are characterized by co-constructed norms and values that provide a framework for symbolic activities, such as goodwill, trust, reciprocity, or transitivity (Monge \& Contractor, 2003). Sligo and Massey (2007) found that un-

Figure 1. Five Processes of Resilience Communication

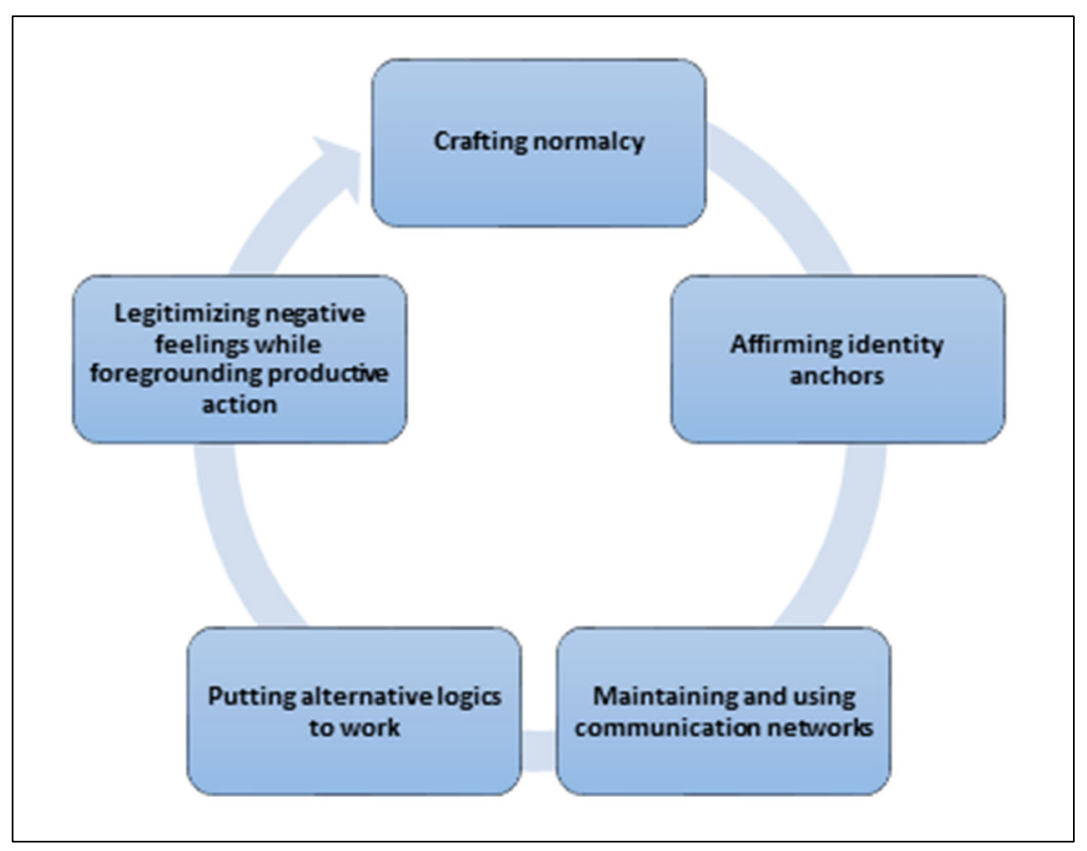

Source: Original figure based on information from Buzzanell, 2010. der conditions of increasing risk, farmers may feel a sense of shared adversity, which may enable higher levels of trust and social networking behavior.

The process of building and using communication networks is essential to resilience because it is through these processes that social capital is developed. Social capital describes the actions or achievements that are derived from the relationships among different actors in a given social structure (Coleman, 1988). Social capital can be developed in interpersonal relationships, including friends, colleagues, and more general contacts (Burt, 1997), as well as through larger formal or informal networks as norms and social trust that facilitate coordination and cooperation for mutual benefit (Putnam, 1995).

The social capital developed in communication networks can support business resiliency. For instance, communicative networks were essential for small businesses in New Orleans to reintegrate after Hurricane Katrina devastated the city in 2005 (Buzzanell, 2010). Kim, Longest, and Aldrich (2013) found that, for new business owners, relying on the social capital developed among their friends, family, and other business owners was a significant contributor to their success. According to Buzzanell (2010), more research is needed to examine how people maintain and use communication networks to be resilient. Recognizing that women farmers face traditional financial and environmental stressors as well as adversity that is unique to their identity, this study aimed to explore how women farmers maintain and use communication networks to be resilient. Specifically, we asked,

R.Q. 1. How do U.S. women farmers maintain and use communication networks in their food systems?

With the goal of supporting resilient women farmers and food systems, we also asked:

R.Q. 2: What economic, envi- 
ronmental, or social value do women farmers' communication practices bring to the resilience of the U.S. food system?

Examining the women farmers' communication networking processes is an important way to contribute to our understanding of how to support women farmers' practices. Further, because women are three times as likely to operate farms that practice sustainable agriculture (Trauger et al., 2008), better supporting women provides benefits to local food and agriculture. We recognize that U.S. women farmers have not had as much agency as they would like when it comes to accessing resources in agriculture. Using interviews with 35 U.S. women farmers, this study seeks to highlight these women's voices.

\section{Methods}

\section{Recruitment Strategy}

The sample used for this study was obtained from a larger set of interviews of women farmers across the United States. Using a criterion sampling method (Lindlof \& Taylor, 2010), interviewees were recruited from the six states with proportionally the most women farmers and proportionally the least women farmers. As determined by preliminary analysis of the 2012 U.S. census of agriculture, states with the highest proportion are Arizona $(45 \%)$, Alaska (43\%), Massachusetts (42\%), New Hampshire (42\%), Maine $(41 \%)$, and Vermont (39\%). Those states determined to have the lowest proportion of women farmers are Ohio (28\%), North Carolina (27\%), Minnesota $(26 \%)$, Iowa $(25 \%)$, Illinois $(23 \%)$, and Kentucky $(18 \%)$. Working with an agricultural outreach specialist whose work focuses on women farmers, we identified key informants from each of these targeted states. These key informants, mostly agricultural extension agents, provided names and contact information for up to 15 women farmers in each of their respective states. Our paper includes analysis of interviews from three states with the highest proportion of women farmers (Alaska, Massachusetts, Vermont) and four with the lowest (Illinois, Iowa, Minnesota, North Carolina). A representation of sample states appears in Figure 2 below.

A team of 11 researchers used email communication to recruit women farmers within their assigned state. To be eligible to participate, a person had to be 18 years or older, identify as a woman, and be the principal farm operator or a farmer when up to three operators were included per farm (per the USDA census of agriculture) for at least six months. Participants were offered a $\$ 50$ incentive for their time and participation.

\section{Sampling}

To explore research questions related to women farmers in sustainable agriculture, the authors analyzed the interviews conducted with all interviewees who were identified as participating in sustainable agriculture. Participants were asked to fill out a demographic survey that included their farming practices, types of products, and market channels, among other demographic questions. Participation in sustainable agriculture was not specifically

\section{Figure 2. States for Women Farmer Interviews}

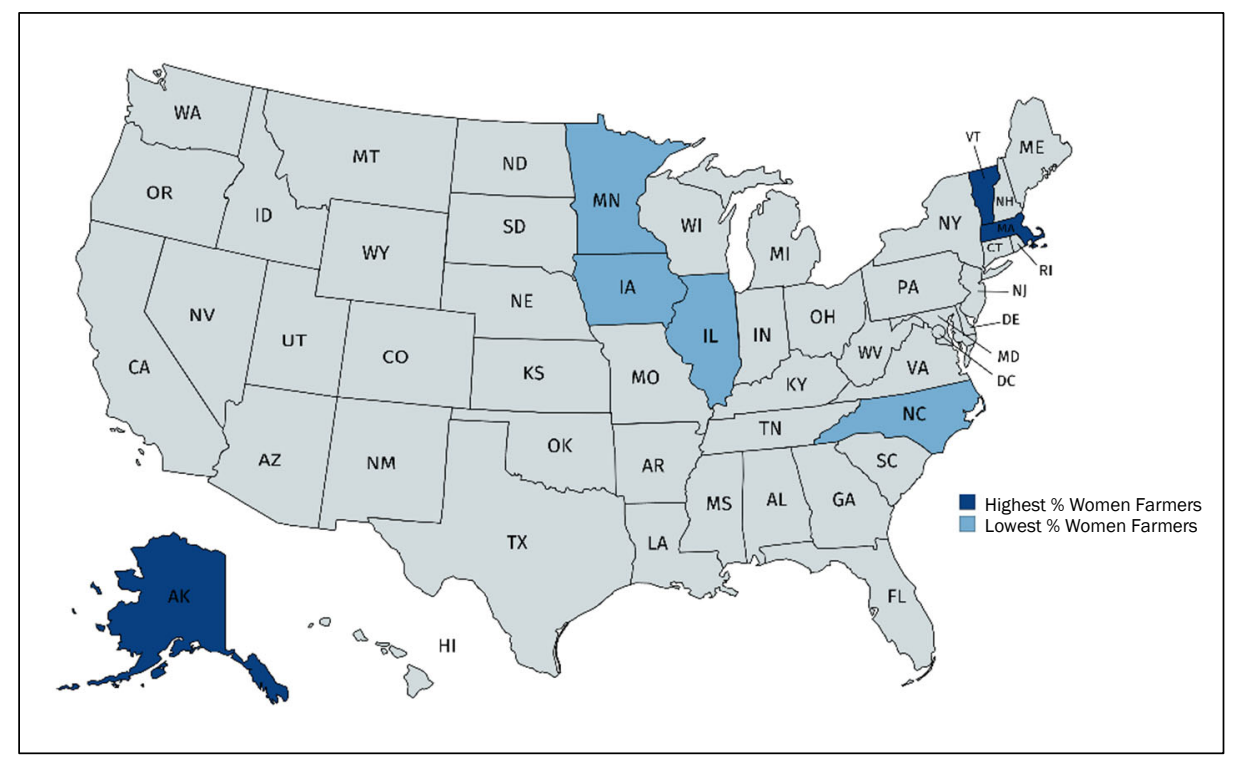


asked; instead, the authors characterized the farmers as such based on participation in alternative market channels such as CSA and farmers' markets, participation in sustainable or organic farming groups, use of the organic label, or self-identification during the interview.

The data set included interviews with 35 women farmers, ages 25-62 (M=41.7). Of the 35 interviewees included in this study, $85 \%$ were firstgeneration farmers, and 50\% had off-farm jobs. All of our interviewees were white. Many different farm types are represented and include diversified fruits and vegetables, dried beans, pasture-raised meat, poultry, dairy, flowers, and medicinal herbs. Farmers typically sold their products through farmer's markets, CSA, restaurants, and direct onfarm sales. Further description of participant farmers is located in Table 1.

There is a lack of diversity in women farmer participants for this study. Specifically, all participants were white, except for one participant who declined to report her race. The demographics of our sample are consistent with the U.S. farm population, given that $95 \%$ of all women farm producers are white (USDA, 2019). This is a problematic statistic that this research is not attempting to dismiss; however, this context is important to include to understand why our research sample lacks heterogeneity. While this study intends to highlight the voices of women farmers, because of its focus on sustainable agriculture and farm operators, it does not address the lack of broad diversity of women in the food chain. Future research should be designed to focus more attention on the intersection of gender, race, sexuality, and socioeconomic status within the food chain.

\section{Interview Strategy}

Semistructured interviews were pre-scheduled and conducted over the phone and lasted 30-60

minutes. Interviews were conducted by 11 different researchers (including the author), who met weekly for 15 weeks to learn about issues surrounding women farmers, resiliency communication, and interview methods together. These researchers coconstructed the interview protocol.

The interviews contained eight questions, including both moderately-closed and open-ended questions. As noted by Berg and Lune (2004), semistructured interviews follow a preconceived interview script, but also give the interviewer "freedom to digress" to explore emergent themes (p. 61). The interview questions were divided into two sections. The first two questions asked the farmer to identify the different formal and informal agricultural networks in which they participated. Based on those responses, we asked interviewees to think about the network with which they felt most connected. The next six questions focused on what the network said or did when responding to individual and collective challenges. Farmers were asked to recall instances when they felt others said or did things to help them or others in the community, as well as what the farmers themselves have said or done to help another person(s) in the network.

Researchers were trained to ask all eight questions, in the same order, and to probe around topics related to resilience, communication, and social support. As such, follow-up questions and probes may have differed slightly based on variations in the interviewees' responses. To perform a cohesive interview process across interviewers and probe in similar manners, the interviewers (including the author) reflected together in person twice a week about the content of the interviews throughout the five-week interview collection process. Emergent themes in the interviews and probing options, as well as problematic questions or wording, were discussed and revised as needed during these meetings.

\section{Analysis Strategy}

Interviews were transcribed verbatim using speechpad.com, an online transcription service. Transcripts were reviewed for accuracy. All farmers and farm names were changed to protect and maintain confidentiality.

We used constant comparative methods to identify themes in the data inductively. Constant comparative analysis is a cyclical and continuous method of processing, reducing, and explaining (Lindlof \& Taylor, 2010). Researchers continually identify codes and themes within and across interviews as well as in comparison to the extant literature (Charmaz, 2005; Lindlof \& Taylor, 2010). The analysis calls for the continual refinement of 
themes as data is collected and formally analyzed through constant comparisons and recoding of the data set (Boeije, 2002).

In our initial analysis, the author read and coded the transcripts multiple times independently until forceful and recurring themes began to emerge from the data. The author consulted with others during the analysis processes to discuss similarities between emerging themes. The author then re-read and recoded the data for opportunities to collapse and consolidate codes. This iterative process continued until no new codes or themes

Table 1. Name and Farm Type for all Participant Farmers

\begin{tabular}{|c|c|c|c|c|}
\hline Farmer Name & Type of Farm & Age & Race & Years Farming \\
\hline \multicolumn{5}{|l|}{ Alaska } \\
\hline Cassi & Diversified vegetables & 46 & White & 10 \\
\hline Lilly & Seeds & 32 & White & 6 \\
\hline Lala & Diversified Vegetables & 61 & White & 38 \\
\hline Milly & Diversified vegetables, Poultry & 61 & White & 20 \\
\hline \multicolumn{5}{|l|}{ Illinois } \\
\hline Abby & Diversified vegetables, Poultry & 43 & White & 3 \\
\hline \multicolumn{5}{|l|}{ lowa } \\
\hline Kelly & Diversified vegetables & 32 & White & 10 \\
\hline Jenna & Diversified vegetables, Meat & 32 & White & 6 \\
\hline Meredith & Bison, Cattle & 42 & White & 14 \\
\hline \multicolumn{5}{|l|}{ Maine } \\
\hline Katy & Organic vegetables & 59 & White & 48 \\
\hline Liz & Organic herbs, greens & 45 & White & 23 \\
\hline Sarah & Vegetables and small fruits & 60 & White & 29 \\
\hline Tasha & Diversified vegetables & 44 & White & 20 \\
\hline Beth & Mixed organic vegetables & 59 & Declined & $>20$ \\
\hline \multicolumn{5}{|c|}{ Massachusetts } \\
\hline Kathleen & Nuts, Diversified fruits & 30 & White & 11 \\
\hline Maddy & Herbs & 30 & White & 8 \\
\hline Nicole & Herbs & 33 & White & 10 \\
\hline Lauren & Meat & 36 & White & 25 \\
\hline Mary & Diversified vegetables, Flowers & 56 & White & 15 \\
\hline Martha & Diversified vegetables & Over 50 & White & 3 \\
\hline \multicolumn{5}{|l|}{ Minnesota } \\
\hline Erin & Flowers & 25 & White & 6 \\
\hline Shelby & Live goats, Goat cheese & 31 & White & 30 \\
\hline Kara & Pork & 34 & White & 14 \\
\hline Jess & Diversified vegetables & 45 & White & 6 \\
\hline Brenda & Diversified fruits and vegetables, Poultry & 62 & White & 11 \\
\hline Sheila & Dry beans, Flint Corn & 62 & White & 13 \\
\hline \multicolumn{5}{|c|}{ North Carolina } \\
\hline Laura & Diversified vegetables, Flowers & 27 & White & 5 \\
\hline Daphne & Diversified vegetables & 41 & White & 15 \\
\hline Olivia & Diversified vegetables, Flowers & 45 & White & 20 \\
\hline Betsy & Diversified fruits and vegetables, Flowers & 46 & White & 20 \\
\hline Bonnie & Diversified fruits and vegetables & 46 & White & 23 \\
\hline \multicolumn{5}{|l|}{ Vermont } \\
\hline Morgan & Diversified fruits, Value-added products & 28 & White & 5 \\
\hline Julia & Diversified vegetables, Poultry & 32 & White & 8 \\
\hline Lydia & Dairy, Maple Syrup & 48 & White & 30 \\
\hline Sophie & Pork, Poultry & 51 & White & 20 \\
\hline Charlotte & Diversified fruits and vegetables, Pork, Poultry & 53 & White & 11 \\
\hline
\end{tabular}


emerged. We used forceful and representative quotes from the interviews to represent the participants' unique voices and to support our claims as researchers (Owens, 1984)

\section{Results}

This study aimed to examine women farmers' communication practices, as well as the value of these practices to their extended farming communities. Through the analysis of 35 interviews with women farmers in sustainable agriculture, we uncovered many ways that women farmers' communication processes interact with and benefit farming communities of practice. Through participants' stories, it was apparent that women were not relying solely on other women farmers for support; many emphasized that they participated in coed networks and benefitted from interactions with both men and women farmers. In addition to gender, women farmers connected with others based on age, crop or livestock type, or farming experience. In this section, we present the ways that individual farmer, farm business, and community level resilience is developed and reified within women farmers' communication networks.

\section{Farmer Resilience}

Many women farmers found that their communication networks developed and supported their personal resilience as farmers. Women reported that at times they were challenged by loneliness, feelings of self-doubt, and the complexities of balancing farm life with home life. Connecting to others provided critical support for enduring the day-to-day and more episodic emotional challenges of farming.

Women farmers reported seeking out and drawing on their existing communication networks to feel connected to others and for support with daily stress. Laura, a farmer in North Carolina in her late 20s, said, "you're at that low, low point, exhaustion and just like confusion. And, you know, you just need some reassurance that everything's gonna be ok." Laura continued to explain that "it's just so uplifting being with people who know exactly what you're going through, the good and the bad....it's just the most healing I think." Meredith, a cattle farmer from Iowa, 15 years her senior, de- scribed the emotional benefits of her network: "You know, we don't have in common what livestock we're raising,...It's really kind of a therapy session, like 'what's new in your world?' And whatever that person responds with it's just a matter of kind of talking them through like, what they're doing and you're doing to just get by in this world really." While there are no definite answers to the farm-related challenges, for Meredith and Laura, realizing that they are not alone changes the reality of their situation. Instead of feeling defeated, women farmers feel empowered to continue.

While some women reported feeling happy, or at least comforted, by interactions with communication networks more generally, many women mentioned feeling best when interacting with specific sub-groups within their networks. For example, women farmers talked about the challenges of being a parent farmer. A mom and farmer from Illinois, Abby, says "we're always talking about how we're juggling being a mom and how she's juggling her business, managing a crew, and managing customers." Bonnie shared that she "commiserated with other growers via Instagram of just realizing that, you know, we weren't the only ones that lost our whole strawberry crop because it was raining so much." While Abby referred to connecting with other moms around stressors related to work-life balance, Bonnie explained how the support of fellow strawberry growers was instrumental in her ability to cope and develop resilience to adverse weather events. Similar to Abby and Bonnie, other farmers found affinity groups, such as groups exclusively for goat farmers or elderberry growers, to have functional benefits to providing support too. Maddy, an herb farmer in Massachusetts, said that "It feels really comforting to be able to talk about those struggles with other people who get it...You don't have to spend a lot of time explaining or breaking down preconceived ideas." Morgan, who grows fruit in Vermont, similarly explained that "It's also really comforting to say, 'Okay, we're in the same boat here.' And then there's like this collective push to figure it out. So, so much of farming is isolating." Groups with comparable experiences were sources of comfort because participants could commiserate quickly. Supporting the resilience of farmers' emotional wellbeing was 
an unspoken value of the networks. As Morgan said,

It's nice to be able to have that interface where you can engage with people for both information but also the emotional piece, which is not obviously advertised, right? It's not like 'Hey, come here for emotional support.' I think it's something intentional that naturally occurs.

Laura, a young farmer, felt particularly uplifted when a woman peer of hers encouraged her to step in for a guest speaker who did not show up for an event and felt especially encouraged because this peer had only ever met her once before. The peer expressed encouragement such as "do it" and "I believe in you," which inspired Laura to sign up to talk about her farming experience at a conference in the future. According to Laura, this type of positive reinforcement from someone she was not particularly close to gave her hope that she was doing the right thing. Morgan and Laura's comments highlight the complex nature of resilience. The need for and ability to offer emotional support was connected. Though these communication networks formed based on shared professions or common interest in a task, the networks also provided emotional support to contribute to the resilience of its members. While Morgan and Charlotte's stories highlight a one-way exchange of support, other farmers' stories demonstrated that resilience practices are complex processes. For example, Julia, an organic vegetable and egg producer in Vermont, highlighted the feeling of community that she gained from using mediated communication (communication over technology channels such as cell phone or computer) with other farmers. She explains, "It makes you feel like you're a part of a bigger network and like there's support out there. And you're not doing it on your own, which is really important."

Similarly, Charlotte, a Vermont farmer, recounted how after her presentation at a meeting, fellow members of the community often reached out to her to "say 'hey, by the way, that helped me' or 'I'm struggling too' and hearing that was validating." Julia and Charlotte's stories demonstrate that providing support does not just help the resilience of the recipient(s) of the message. Rather, the source of the message also built their own confidence and reified their sense of resilience through their participation in the network.

\section{Farm and Business Support}

\section{Seek and Share Information}

The sharing of technical support and farmer to farmer information was central to women farmers' networking practices in sustainable agriculture. For example, Bonnie, a farmer in North Carolina, hosted events to help new young woman farmers "start to feel like there's more of a community group that each other can come to with, like, problems or anything else, friendship." In addition to hosting meals, Lydia, a dairy farmer in Vermont, thought it was important to provide networking opportunities to help farmers access resources, stating, "We try to host some workshops and learning opportunities for other farmer members." Lily, a woman farmer in Alaska, said that her Facebook seed group was able to "come up with constantly creative solutions from the advice they give others and learning about their space." Describing similar conferences and workshops, Liz, a Maine organic vegetable farmer, said, "I think that [networking at conferences] greatly, greatly supports our resilience as farmers both relationally and technically... We're always learning. We take away some gems from anytime we see another farmer, and we ask them a question."

Similarly, Bernadette, a first-generation tree fruit farmer from Massachusetts, said "I just wouldn't know where to start if it weren't for, you know, being able to reach out to other growers or to my extension." These women's experiences help highlight how women farmers in a variety of geographic areas are using networking. In addition, they establish a norm of reciprocity that supports communication networks and the participants' resilience.

Building and maintaining communication networks using communication technologies emerged as particularly useful for many women farmers who did not always have other farmers close by to ask. Karen explained that interactions 
within her communication network "feel really powerful to me and helpful, because, especially looking for information, you get a quick response to a question especially if it has a time consideration." For Karen, the ability to get information quickly from her online network was important because many of her concerns required timely responses. Tasha, a diversified crop farmer in Maine, said agricultural listservs provide a forum to ask questions on a variety of topics such as "insect control, or QuickBooks issues, or labor issues, and sometimes, like, a new tool or implement that somebody wanted to try and is asking if anybody has one to see what their opinion is on it." Similarly, Charlotte, an organic farmer in Vermont, explained that "the hashtag capacity of Instagram enables me to be networked with everyone... and get a lot of information from farmers via that process." For Tasha and Charlotte, mediated communication was valuable because it allowed them to access a variety of information more quickly and efficiently than they could do otherwise. Social media features, like hangtags, allowed them to refine the relevance of conversations within their networks even further.

In addition to being able to access information quickly, women farmers reported using mediated communication networks to overcome challenges related to geographic space. Lilly, a woman farmer in Alaska, explained how mediated interactions with other farmers allowed her to transcend the isolation of her rural setting. She explained that face-to-face communication was not a reliable source of support because there was not a "single person to ask in the surrounding area." Instead, Lilly relied on social media platforms, such as Facebook, to connect with others and gain valuable information and technical support. Similarly, Daphne, an experienced woman farmer in North Carolina, said that there were not many small farmers in the region, and those that are there are very spread out. She said she goes to the potluck gatherings and conferences to "connect" with likeminded farmers and ask "questions across the board about all aspects of farming." Because these networking events included small groups of smallscale farmers in the region, Daphne felt as though the information and support exchanged during networking events was unique and very helpful to her resilience.

In addition to gaining access to valuable information they would not have otherwise had easy access to, women farmers explained that communication networks provided them with critical spaces for collaborative problem solving and business practices. For example, sick animals are a major stressor to an animal farmer that demand quick responses. Email listservs were commonly used for solving problems related to animal health. Margaret, a New Hampshire poultry farmer, spoke of using a listserv to diagnose illness in her chickens. "If my chicken is sick, you know, [I'll ask] what does this look like? People are like, 'oh, it looks like bumble foot'... It's very helpful, not just chit chatty." Similarly, Susan, a shepherdess from New Hampshire, talked about how a grazers listserv helped her triage her animals. She said:

It could be, 'I've got a weak lamb, I don't know what's wrong with it.' And then they talk about white muscle disease and some professor somewhere will give you links to find out more about that. Or somebody will say, 'Call a vet immediately. This is not something for the list.'

Both farmers found communication within their networks valuable because it helped them make sense of the problems and identify potential solutions. Susan's comment is interesting because in her story, someone said that the topic transcended the expertise of the network, so Susan should seek outside, expert help immediately. While communication networks were helpful to protect the resilience of participants, there were still some boundaries that the groups had to navigate. Participants are aware of the collective's expertise and therefore self-monitor information sharing to protect members.

\section{Collaborative Practices}

In addition to benefiting as individual farmers from information sharing, women farmers and their farms drew on their communication networks to collaborate and coordinate. Many women farmers said that they shared business strategies and devel- 
oped collaborative business practices within their communication networks. Betsy, a fruit and vegetable grower in North Carolina, said that farmers are "working together, and often will buy things together like fertilizer, soil or things where we can save money if we buy in bulk quantity." Similarly, Julia told an analogous story about her farm in Vermont, saying that multiple farms often placed orders together to save on shipping costs. It was also common for the networks to seek and offer help with labor-intensive tasks or in the wake of a natural disaster. Many women farmers participated in "barn-raising events" or got together to build hoop houses, where farmers provided snacks or a meal in return for help establishing these structures. Cassi, a vegetable farmer in Alaska, talked about a particular farmer in her area that needed 20,000 bulbs planted at her farm each fall. During this time, an informal network of farmers she built through a local farmers' market coordinated to "go over there and just bang it out in one day." Without the help of the people in her network, this work would have taken weeks. Getting the work completed quickly allowed Cassi to focus her attention on other areas of her farm. Owning and operating a farm involves financial uncertainty due to market challenges and difficult-to-anticipate externalities that affect yields. Collaboration and help, made possible by their communication networks, provided financial breaks that were critical to the resilience of women farmers and their farms. During times of crisis, on-farm help becomes more time-sensitive and heightens the need for efficient communication. Tasha talked about a time when she received a message for help from another farmer via their local organic growers association after wind caused the plastic of a hoop house to blow off. As she recalled, "they emailed and said, 'Hey. I'm in a pinch right now. I need to get the plastic back on. Can you come help?"' In another interview, Erin from Minnesota recounted local farmers' reactions to recent massive flooding on surrounding farms:

We were all trying to reach out to each other, mostly by text or email..., and just try and figure out how everyone was doing...'How's this person's farm?' How's this person's farm? So, we had this email thread of like, you know, 'Erica's farm, everything washed away. Can we try and get people over to, you know, replant, see what she needs?'

Tasha and Erin's stories demonstrated how, when already established, women farmers can draw on their communication networks to support each other's weather-related farm resilience. Similar to identifying relevant information quickly, mediated communication within the networks proved an efficient way of identifying needs and organizing volunteers during times of crisis.

\section{Resilient Communities of Practice}

While networks directly supported women farmers and their businesses by sharing informational and collaborative practices, women also discussed the notion of wanting to do so to promote the values of sustainable agriculture. Specifically, women farmers reported that their mentoring and information sharing practices violated expectations that businesses should be competitive. Operating under norms and goals that violated the expectations of profit-oriented values, these farmers perceived their networks as strengthening the resilience of the sustainable agriculture community more generally.

Mentoring the next generation of farmers was an emerging theme within the stories of supporting the resilience of the sustainable agriculture community. Many women interviewed in the study valued farm models that provided opportunities for volunteers and mentorship. For example, some farmers worked on land that was designed to have older, more experienced mentors training new farmers. This was typically on a temporary basis, where farmers would eventually move on to acquire their own land. Cassi, a vegetable and poultry farmer, explained that the purpose of hosting volunteer and mentorships is "to help teach people, the next generation..., it doesn't even matter what age group, help pass on knowledge that I have about how to farm, and just sort of inspire others on whatever scale." On-farm mentoring provided less-experienced farmers with opportunities to learn the skills and information needed to help their businesses and farms succeed. In addition to 
learning, mentorships and volunteering supported the resilience of farmers. Maddy, an herb farmer in Massachusetts, said she built lasting relationships with former employers and mentors who are still her "biggest source of support" today. For Maddy, the support helped her launch her farm business and keep it viable beyond the initial startup. Helping less experienced farmers is a means of increasing or maintaining the number of farmers in sustainable agriculture.

In addition to directly contributing to the resilience of individual newcomers, women farmers reported contributing to the resilience of the sustainable agriculture community by creating norms of support. As Morgan said in her interview, "I got advice from other people, so I feel obligated to say, 'Okay, I'll give you the 20 minute phone call and tell you what I've learned and what I'm learning.' And it's not always the most convenient, and sometimes it can feel burdensome. But once again, just giving back to the farmer to farmer model." Morgan's comment reflected how feeling supported by others encouraged her to pass on what she has received to others. Morgan and Cassi's stories stressed the importance of perpetuating farming knowledge for the continued support and growth of the sustainable agriculture sector.

Many farmers' stories emphasized the importance of information sharing within the greater farming communities. For example, many interviewees reported sharing business plans and marketing strategies, including names of local restaurants and markets well-suited for farm sales. Milly, an organic poultry farmer from Alaska, explained how communication within her network deviated from that which she experienced with men farmers. She explained:

Well, I think farmers sort of have always held their cards close to their chest, where they don't really wanna share too much information because it's seen as a competition kind of thing. But I think that's changing somewhat, and I do think that women farmers, at least in my experience, are more open to that sharing of information, and not...and I don't know if it's just the nature-nurture thing or what it is, women are just nicer than men, I don't know.
But yeah, there does seem to be more willingness to sort of really invite people to come over and see what you're doing, and to help build...just because you're helping somebody else build up their farm, it helps you build up your farm. So it's not like, "If you're selling more produce, then I'm gonna sell less. "It's, "If you're selling more, then I'm gonna sell more," because that increases sort of the public awareness of the whole thing. So I do think that female farmers are better at that than our male counterparts.

Jess, a vegetable grower from Minnesota, used to feel uncomfortable asking for advice from a local farmer selling the same crop. "We're such a competitive society," she said, "you think, are they really gonna wanna give you advice when you're like right down the road, and you're trying to sell the same stuff?... Like, no. They're fine with it. And then you try to pay it forward, too." Milly and Jess's experiences suggested that their communication networks prioritized the collective well-being of farm businesses, even at the cost of any individuals' financial edge. Milly, unlike Jess, attributed this difference to the gendered identities of the participants. Both Jess and Milly recognized that their communication networks adopted practices that were in opposition to mainstream culture in the U.S., specifically, competitive business models. Both women suggested that the alternative forms of communication caused some initial uncertainty around asking for information or help. However, witnessing or experiencing norms of generosity and reciprocation within resilience communication seemed to ease those tensions and assimilate the women into the network. In other words, generosity within the group inspired other members to do or want to do likewise. Because members of the group were contributing to each other's individual resilience, each member could trust that their business' resilience would be supported if threatened.

In addition to trusting that others would be supportive, some farmers suggested that openness and trust were important to support the resilience of the sustainable agriculture community in the face of a common opposition. Betsy, a farmer in North Carolina, explained that it is in the best in- 
terest of participants to contribute to each other's farm and business resilience because they are all trying to defend themselves against powerful competition. She explained, "it's not really us [other farmers] we're in competition with, we're in competition with Walmart, and, you know, big grocery stores and stuff." Charlotte, a farmer from Vermont, called it a "win-win-win" when you help other farmers. By this, Charlotte indicated that the benefits extend beyond her own economic well-being through practices that benefit the environment and simultaneously build resistance to organizations with competing ideologies.

The values of trust and sharing among farmers were common among interviewees, but not universal. Some women discussed tensions surrounding when, what, and how much to disclose to other farmers. These typically did not reflect the values of the participants themselves, but of nearby farmers with whom they had interacted. For example, Bernadette, a farmer in Massachusetts, mentioned, "not everybody gives up their [growing] secrets." Mary, also a farmer in Massachusetts, reported that she was willing to "share anything with anybody," but that some farmers "are kind of secretive and want to keep their knowledge to themselves because it may gain them something, but I'm not really like that." By emphasizing that they share information, but not everyone does, Bernadette and Mary's comments reflected their network's value of sharing. However, comments like these are also important reminders that farmers participating in these networks have competing financial and social considerations that they must navigate.

In addition to supporting the farm and business, our interviewees felt that their communication practices helped retain members of their farming communities. Julia, from Vermont, said the support provided in networks was particularly vital for new farmers. She explains, "There's a lot of people who get into farming, and then after a few years, they quit for one reason or another." She explained that there have been issues of poor mental health and farmer retention in her farming community. In response, she says, "We try to bring people, connect people together."

Similarly, Bonnie, a farmer in North Carolina, said that she hosted events to help new young woman farmers "start to feel like there's more of a community group that each other can come to with, like, problems or anything else, friendship." Both Julia and Bonnie described how, in addition to providing information and help with the farm business, the networks try to help women farmers overcome physical and social isolation through community-building activities. The assumption was that women farmers would stay in the profession longer and would have stronger mental health if they were in the community. This communication pattern reflects an unspoken responsibility of the group to protect the sustainable agricultural community as a whole by serving as the protectors of each other's happiness and health. The community is responsible for the resilience of the community.

\section{Discussion}

From potlucks to social media discussions to workshops and formal networking events, women farmers found a variety of ways to build and maintain communication networks. These networks included both all-women and coed groups, and women found support through interaction with men and women. Conversation within women farmers' communication networks contributed to and reified the resilience of the individual farmers, their farm business, and the greater sustainable agriculture community. Women were able to build and maintain networks and support their resilience through seeking and sharing information and collaborative business practices daily. If networks were already in place, women farmers could also draw on their networks for quick and effective hands-on support during times of crisis.

\section{Theoretical Implications}

Buzzanell (2010) theorizes that maintaining and using communication networks helps enable individuals to persevere either in response to a catastrophic event or in the face of consistent and recurring challenges. For farmers in our study, these challenges included feelings of isolation, crop failures, unexpected weather events, financial challenges, or the constraints of working in a maledominated industry. This study contributes to Buzzanell (2010) and provides deeper insight into understanding the value of communication networks 
in maintaining resilience. Women farmers developed and maintained communication networks to support their resilience in sustainable agriculture. Farmers are typically either geographically isolated from their neighbors or, if not, their neighbors may not understand the unique challenges this population faces. Therefore, having someone close by to talk to and make sense of challenges is not always an option. Transcending time and geographic space, mediated forms of communication in these networks were critical to women farmers' resilience.

Our findings also complement and contribute to Houston's (2018) theory of community resilience. As Houston argued, a community of resilient individuals does not automatically constitute a resilient community. Rather, "dynamic interactions" make a collective of individuals a resilient whole ( $\mathrm{p}$. 21). We agree with Houston's (2018) argument, the collective engagement of resilient women farmers contributes to and reifies the resilience of their larger network and sustainable agriculture community. Participants grew as they received and gave support. The giving and receiving of support had a generative effect, supporting the continued resilience practices of the group.

Our study's most valuable contribution to resilience theorizing is extending Houston's (2018) argument to include communities of practice, not just communities of place. Instead of being motivated through a shared connection to a local community, support within the communication networks was fostered through the shared goal of advancing the sustainable agriculture movement. Our findings are consistent with a study done by Hassanein and Kloppenburg (1995), which suggests that networks of information sharing propel the sustainable agriculture movement on dairy farms in Wisconsin. Our study advances this work by exploring the dual benefits of communication networks on both individual and broader community resilience. Future research should continue to explore how communities of practice in agriculture and other fields can foster resilience for members and the community.

Prior scholars have argued that farmers in sustainable agriculture operate within a separate paradigm, one that is concerned more about connecting to and protecting the earth than about money (Bell, 2004; Trauger et al., 2008). While women farmers emphasize norms of openness, generosity, and collaboration, we also identified counter cases that suggest hesitation, or an unwillingness to disclose techniques or engage in dialogue with other farmers. Future research should examine how communication within the sustainable agriculture community helps farmers make sense of this tension as well as the impact of that sense-making on a farmer, farm business, and sustainable agriculture's resilience.

\section{Practical Implications}

This study demonstrates how building and maintaining communication networks contributes to women farmers and their greater community's resilience. Women farmers and professionals supporting women farmers should prioritize communication by seeking ways to initiate and develop networks, as well as ways to foster access and active engagement within the networks. This study's findings highlight the imperative of providing equitable access to networking opportunities for women farmers. In particular, interviewee stories included direct accommodations that relevant organizations could implement to increase farmer participation:

1. Support informal networking events, as well as formal networking events. Women farmers reported gaining information at formal events such as extension workshops and conferences. However, informal networking activities, such as social media activity or potlucks, provided space for information and resource sharing as well as relationship building. Encourage relationship building and self-organized activities that transcend the actual event and help build or maintain a communication network.

2. Within networks of farmers, women reported that they found support through interactions with all genders. This is important information for organizations to know, as women were more likely to seek support from others based on similar expe- 
riences than by gender. They discussed seeking out other women when the challenges were related to being a woman farmer. However, given the frequency of crop, livestock, or financial challenges, women farmers were also seeking others with a similar farm or business type.

3. The findings of this study highlight the need for increased farmer access to communication technologies and wifi. For women farmers who felt isolated due to geography or the nature of small-scale farm work, internet platforms such as email listservs and social media were critical for access recourses and support. Policy-makers and other organizations that advocate for farmers should note this importance. In addition to increasing access, educators can facilitate training on how to use communication technologies or the different types of support that can be provided. Future research should examine if farmers prefer organizations to host online networking activities or if they prefer to self-organize.

4. Interviewees provided positive feedback for on-farm mentoring models. Farms that encouraged mentoring and hosting volunteers not only increased the depth of learning for beginning farms but forged strong bonds between multiple generations within agriculture. This is particularly important given that most farmers within this movement have been first generation.

\section{Limitations and Future Research}

Based on recruitment strategies for this project, it is likely that participant farmers are systematically more connected to agricultural networks than nonparticipants. Key informants from each state were typically affiliated with their state's extension or a local farming association. Therefore, farmers they identified for the study were ones they would know through these networks. By nature of being identifiable, we can assume that farmers have larger net- works than their non-identifiable peers. Another reason that participants may have been disproportionately engaged in social networks is that most were in their first ten years of farming. Over a quarter of farmers in the U.S. fall into this "beginning farmer" category (USDA, 2019). However, as a population, this subgroup may be disproportionately more likely to tap into their support networks compared to their more seasoned peers because they have a smaller stock of knowledge for problem shooting.

Since all participants in this study are white, our analysis lacks the experiences and perspectives of women of color who operate farms. While 95\% of women farmers in the U.S. are white (USDA, 2019), organizations should be careful not to assume the findings of this study apply to all U.S. women farmers. Future research should focus more attention on the intersection of gender, race, sexuality, and socioeconomic status within the food chain.

Our findings are also limited in their ability to conceptualize resilience communication fully because all the interviewees were still participating in agriculture. They are practicing resilience in some form. The design of this study did not allow for the voices of those who had exited farming, by choice or otherwise. Future research should add to the richness of our findings by expanding the sample to learn why women farmers chose not to continue their participation and the support they did or did not find.

\section{Conclusion}

Women farmers' numbers are continuing to increase, as well as their prominence in conversations within sustainable agriculture. This study highlighted the ways in which our interviewees used their communication practices within in-person and online forms of agriculture networks to maintain individual resilience as farmers, while collectively supporting the growth and interactive nature of the sustainable agriculture movement. The findings from this study and subsequent developments will help ensure continued support for these resilience processes. 


\section{References}

Allen, P., \& Sachs, C. (2011). Women and food chains: The gendered politics of food. In P. Williams-Forson \& C. Counihan (Eds.), Taking food public: Redefining foodways in a changing world, (pp. 23-40). Routledge.

Allen, P., Van Dusen, D., Lundy, J., \& Gliessman, S. (1991). Integrating social, environmental, and economic issues in sustainable agriculture. American Journal of Alternative Agriculture, 6(1), 34-39. https://doi.org/10.1017/S0889189300003787

Altieri, M. A. (2009). Agroecology, small farms, and food sovereignty. Monthly review, 61(3), 102-113.

Barbercheck, M., Brasier, K., Kiernan, N. E., Sachs, C., \& Trauger, A. (2014). Use of conservation practices by women farmers in the Northeastern United States. Renewable Agriculture and Food Systems, 29(1), 65-82. https://doi.org/10.1017/S1742170512000348

Barbercheck, M., Brasier, K. J., Kiernan, N. E., Sachs, C., Trauger, A., Findeis, J., Stone, A., \& Moist, L. S. (2009). Meeting the extension needs of women farmers: A perspective from Pennsylvania. Journal of Extension, 47(3), 1-11. Retrieved from https://www.joe.org/joe/2009june/a8.php

Bell, M. M. (2004). Farming for us all: Practical agriculture and the cultivation of sustainability. University Park, PA: The Pennsylvania State University Press.

Berg, B. L. \& Lune, H. (2011). Qualitative research methods for the social sciences. Upper Saddle River, NJ: Pearson Education.

Beus, C. E., \& Dunlap, R. E. (1990). Conventional versus alternative agriculture: The paradigmatic roots of the debate. Rural sociology, 55(4), 590-616. https://doi.org/10.1111/i.1549-0831.1990.tb00699.x

Boeije, H. (2002). A purposeful approach to the constant comparative method in the analysis of qualitative interviews. Quality and Quantity, 36, 391-409. https://doi.org/10.1023/A:1020909529486

Brasier, K., Barbercheck, M., Kiernan, N. E., Sachs, C., Schwartzberg, A., \& Trauger, A. (2009). Extension educators' perceptions of the educational needs of women farmers in Pennsylvania. Journal of Extension 47(3), 1-12. Retrieved from https://www.joe.org/joe/2009june/a9.php

Brew, B., Inder, K., Allen, J., Thomas, M., \& Kelly, B. (2016). The health and wellbeing of Australian farmers: A longitudinal cohort study. BMC public health, 16(1), 988. https://doi.org/10.1186/s12889-016-3664-y

Burt, R. S. (1997). A note on social capital and network content. Social networks, 19(4), 355-373. https://doi.org/10.1016/S0378-8733(97)00003-8

Buzzanell, P. M. (2010). Resilience: Talking, resisting, and imagining new normalcies into being. Journal of Communication, 60(1), 1-14. https://doi.org/10.1111/j.1460-2466.2009.01469.x

Charmaz, K. (2005). Grounded theory in the 21st century: Applications for advancing social justice research. In N. K. Denzin \& Y. S. Lincoln (Eds.), The Sage handbook of qualitative research, (pp. 507-535). Sage Publications Ltd.

Chiappe, M. B., \& Butler Flora, C. (1998). Gendered elements of the alternative agriculture paradigm. Rural Sociology, 63(3), 372-393. https://doi.org/10.1111/j.1549-0831.1998.tb00684.x

Coleman, J. S. (1988). Social capital in the creation of human capital. American Journal of Sociology, 94, S95-S120. https://doi.org/10.1086/228943

Hassanein, N. (1997). Networking knowledge in the sustainable agriculture movement: Some implications of the gender dimension. Society \& Natural Resources, 10(3), 251-257. https://doi.org/10.1080/08941929709381024

Hassanein, N. (1999). Changing the way America farms: Knowledge and community in the sustainable agriculture movement (Vol. 12). Lincoln: University of Nebraska Press.

Hassanein, N., \& Kloppenburg Jr, J. R. (1995). Where the grass grows again: Knowledge exchange in the sustainable agriculture movement. Rural Sociology, 60(4), 721-740. https://doi.org/10.1111/j.1549-0831.1995.tb00603.x

Houston, J. B. (2015). Bouncing forward: Assessing advances in community resilience assessment, intervention, and theory to guide future work. American Behavioral Scientist, 59(2), 175-180. https://doi.org/10.1177/0002764214550294

Houston, J. B. (2018). Community resilience and communication: Dynamic interconnections between and among individuals, families, and organizations. Journal of Applied Communication Research, 46(1), 19-22. https://doi.org/10.1080/00909882.2018.1426704 
Horst, M., \& Marion, A. (2019). Racial, ethnic and gender inequities in farmland ownership and farming in the U.S. Agriculture and Human Values, 36, 1-16. https://doi.org/10.1007/s10460-018-9883-3

Jarosz, L. (2011). Nourishing women: Toward a feminist political ecology of community supported agriculture in the United States. Gender, Place \& Culture, 18(3), 307-326. https://doi.org/10.1080/0966369X.2011.565871

Keller, J. C. (2014). “I wanna have my own damn dairy farm!': Women farmers, legibility, and femininities in rural Wisconsin, U.S. Journal of Rural Social Sciences, 29(1), 75-102. Retrieved from https://egrove.olemiss.edu/jrss/

Kim, P. H., Longest, K. C., \& Aldrich, H. E. (2013). Can you lend me a hand? Task-role alignment of social support for aspiring business owners. Work and Occupations, 40(3), 213-249. https://doi.org/10.1177/0730888413481365

Leckie, G. J. (1996). 'They never trusted me to drive': Farm girls and the gender relations of agricultural information transfer. Gender, Place \& Culture, 3(3), 309-326. https://doi.org/10.1080/09663699625586

Leslie, I. S., \& White, M. M. (2018). Race and food: Agricultural resistance in U.S. history. In P. Batur \& J. Feagin (Eds.), Handbook of the sociology of racial and ethnic relations (pp. 347-364). Handbooks of Sociology and Social Research. Springer, Cham. https://doi.org/10.1007/978-3-319-76757-4_19

Leslie, I. S., Wypler, J., \& Bell, M. M. (2019). Relational agriculture: Gender, sexuality, and sustainability in U.S. farming. Society \& Natural Resources, 32(8), 853-874. https://doi.org/10.1080/08941920.2019.1610626

Lindlof, T. R., \& Taylor, B. C. (2010). Qualitative communication research methods (3rd ed). Thousand Oaks, CA: SAGE Publications.

Long, Z., Buzzanell, P. M., Wu, M., Mitra, R., Kuang., K., \& Suo, H. (2015). Global communication for organizing sustainability and resilience. China Media Research, 11(4), 67-77. Retrieved from http://www.chinamediaresearch.net/

Manyena, S. B., O’Brien, G., O’Keefe, \& Rose, J. (2011). Disaster resilience: A bounce back or bounce forward ability? Local Environment, 16(5), 417-424. https://doi.org/10.1080/13549839.2011.583049

Monge, P. R., \& Contractor, N. S. (2003). Theories of communication networks. Oxford University Press, USA.

Monge, P., Heiss, B. M., \& Margolin, D. B. (2008). Communication network evolution in organizational communities. Communication Theory, 18(4), 449-477. https://doi.org/10.1111/j.1468-2885.2008.00330.x

Norris, F. H., Stevens, S. P., Pfefferbaum, B., Wyche, K. F., \& Pfefferbaum, R. L. (2008). Community resilience as a metaphor, theory, set of capacities, and strategy for disaster readiness. American Journal of Community Psychology, 41 (1-2), 127-150. https://doi.org/10.1007/s10464-007-9156-6

Owens, W. F. (1984). Interpretive themes in relational communication. Quarterly Journal of Speech, 70(3), $274-287$. https://doi.org/10.1080/00335638409383697

Peter, G., Bell, M. M., Jarnagin, S., \& Bauer, D. (2000). Coming back across the fence: Masculinity and the transition to sustainable agriculture. Rural Sociology, 65(2), 215-233. https://doi.org/10.1111/j.1549-0831.2000.tb00026.x

Pilgeram, R. (2019). "How much does property cost up there?”: Exploring the relationship between women, sustainable farming, and rural gentrification in the U.S. Society \& Natural Resources, 32(8), 911-927. https://doi.org/10.1080/08941920.2018.1530818

Putnam, R. D. (1995). Tuning in, tuning out: The strange disappearance of social capital in America. P.S.: Political Science \& Politics, 28(4), 664-683. https://doi.org/10.2307/420517

Pyrko, I., Dörfler, V., \& Eden, C. (2017). Thinking together: What makes communities of practice work?. Human Relations, 70(4), 389-409. https://doi.org/10.1177/0018726716661040

Richardson, G. E. (2002). The metatheory of resilience and resiliency. Journal of Clinical Psychology, 58(3), $307-321$. https://doi.org/10.1002/jclp.10020

Sachs, C. E., Barbercheck, M. E., Brasier, K. J., Kiernan, N. E., \& Terman, A. R. (2016). The rise of women farmers and sustainable agriculture. Iowa City: University of Iowa Press. https://doi.org/10.2307/j.ctt20p57gr

Shisler, R. C. \& Sbicca, J. (2019). Agriculture as carework: The contradictions of performing femininity in a maledominated occupation. Society \& Natural Resources, 32(8), 875-892. https://doi.org/10.1080/08941920.2019.1597234

Sligo, F. X., \& Massey, C. (2007). Risk, trust and knowledge networks in farmers' learning. Journal of Rural Studies, 23(2), 170-182. https://doi.org/10.1016/j.jrurstud.2006.06.001

Trauger, A. (2004). 'Because they can do the work': Women farmers in sustainable agriculture in Pennsylvania, USA. Gender, Place \& Culture, 11(2), 289-307. https://doi.org/10.1080/0966369042000218491 
Trauger, A., Sachs., C., Barbercheck, M., Brasier, K., \& Kiernan, N. E. (2010). “Our market is our community”: Women farmers and civic agriculture in Pennsylvania, USA. Agriculture and Human V alues 27(1), 43-55. https://doi.org/10.1007/s10460-008-9190-5

Trauger, A., Sachs, C., Barbercheck, M., Kiernan, N. E., Brasier, K., \& Findeis, J. (2008). Agricultural education: Gender identity and knowledge exchange. Journal of Rural Studies, 24(4), 432-439. https://doi.org/10.1016/j.jrurstud.2008.03.007

USDA, National Agricultural Statistics Service [USDA NASS]. (2014). 2012 census of agriculture. Retrieved from https://www.nass.usda.gov/Publications/AgCensus/2012/

USDA, National Agricultural Statistics Service [USDA NASS]. (2019). 2017 census of agriculture. Retrieved from https://www.nass.usda.gov/Publications/AgCensus/2017/index.php

Wenger, E., McDermott, R., \& Snyder, W. M. (2002). Cultivating communities of practice: A guide to managing knowledge. Boston, MA: Harvard Business School Press.

Wypler, J. (2018). Lesbian and queer sustainable farmer networks in the Midwest. Society \& Natural Resources, 32(8), 947-964. https://doi.org/10.1080/08941920.2019.1584834 